\title{
Popularitas Gamelan Gong Kebyar Dalam Arena Pertarungan Kekuasaan Gamelan Bali
}

\author{
Kadek Anggara Rismandika ${ }^{1}$
}

\begin{abstract}
Gong kebyar is the most popular Balinese gamelan ensemble. Gong kebyar is a new class of Balinese gamelan created between 1910 and 1915 in the north of Bali. The popularity of gong kebyar is used as a medium in the arena of power struggles. The analysis of this study uses the ethnomusicology point of view in discussing gong kebyar in the context of Balinese culture and sociology discipline to discuss gong kebyar in social scope critically. "Kebyar" refers to the Bourdieu power theory that used as a cultural capital in the arena of Balinese gamelan power struggle. Gong kebyar through cultural capital of the symbolic value "kebyar" gained dominance in the arena of Balinese gamelan power struggle. Balinese gamelan outside gong kebyar experiencing changes in the form of "tabuh gong" is the inclusion of the "tabuh gong" which is the identity of musical character of Gong kebyar.
\end{abstract}

Keywords: gong kebyar, kebyar, cultural capital, Balinese gamelan.

\begin{abstract}
Abstrak
Gong kebyar adalah ansambel gamelan Bali yang paling popular. Gong kebyar masuk dalam gamelan Bali golongan baru yang diciptakan antara tahun 1910 sampai 1915 di Bali utara. Popularitas gong kebyar digunakan sebagai media dalam arena pertarungan kekuasaan. Analisis penelitian ini menggunakan sudut pandang disiplin etnomusikologi dalam membahas gong kebyar dalam konteks budaya Bali dan disipiplin sosiologi untuk membahas gong kebyar dalam ruang social secara kritis. "Kebyar" mengacu dari teori kekuasan Bourdieu digunakan sebagai capital budaya dalam arena pertarungan kekuasaan gamelan Bali. Gong kebyar melalui capital budaya dari nilai simbolik "kebyar" memperoleh dominasi dalam arena pertarungan kekuasaan gamelan Bali. Gamelan Bali di luar gong kebyar mengalami perubahan bentuk tabuh gong yaitudimasukkannya tabuh gong yang merupakan identitas karakter musikal gong kebyar.
\end{abstract}

Kata kunci: gong kebyar, kebyar, capital budaya, gamelan Bali.

\footnotetext{
${ }^{1}$ Mahasiswa Program Pascasarjana ISI Yogyakarta.
} 


\section{Pendahuluan}

Gong kebyar adalah salah satu jenis gamelan Bali yang dikenal sebagai identitas masyarakat Bali, khususnya dalam seni musik. Jika ada yang bertanya gamelan apa yang paling populer di Bali saat ini maka jawabannya hampir dapat dipastikan yaitu gong kebyar (Dibia, 2012: 115). Gong kebyar sangat populer di dalam maupun di luar negeri (Bandem, 2008: 111). Gong kebyar sebagai identitas sering kali dilihat sebagai hasil dari upaya masyarakat yang giat melestarikan dan memperkenalkannya ke seluruh dunia. Melalui gong kebyar masyarakat Bali memperoleh identitasnya. Gong kebyar selalu ditampilkan dalam acara-acara bernuansa diplomasi kebudayaan melalui misi-misi kesenian Bali yang dikirim pemerintah daerah atau pusat ke luar negeri (Aryasa, 2008: 67). Melalui gong kebyar masyarakat Bali memperkenalkan dirinya sebagai salah satu ikon pariwisata dunia milik Indonesia atas nama seni dan budaya.

Gong kebyar adalah ansambel gamelan Bali yang bertonika 5 (lima) nada atau pentatonis yang melahirkan musik-musik bernafas kebyar (Aryasa, 2008: 65). Istilah "kebyar atau senikakebyaran" yang menjadi ciri khas bentukpenciptaankaryadariansambel gamelan gong kebyar merupakan identitas musiknya. Kebyar atau senikakebyaran merupakan istilah yang ditujukan untuk jenis musik secara bentuk musik instrumental atau iringan tari secara keseluruhan. Seni kakebyaran pada awalnya lahir sebagai sebuah ekspresi musikal (tabuh gong) berupa tetabuhan dengan bunyi keras yang datang secara tiba-tiba, menggelegar dan meledak-ledak (Dibia, 2008: 2). Kebyar sebagai ciri khas kaitannya dengan bentuk musikal dan keutuhannya merupakan identitas gong kebyar.

Bentuk musikal dalam istilah karawitan Bali pada umumnya diistilahkan tabuh gong. Karakter musical tabuh gong kebyar memiliki ciri-ciri tempo cepat, rumit, keras dan dinamis menjadi sumber acuan penciptaan karya untuk ansambel gamelan Bali yang lain. Karakter musical tabuh gong kebyar diimitasi kedalam jenis ansambel gamelan Bali di luar gong kebyar dengan alasan pengembangan dan pembaharuan. Prinsip pinjam meminjamkan dan transformasi terjadi dalam ansambel-ansambel gamelan di Bali (Bandem, 2008: 115). Kebyar sebagai 
sumber acuan penciptaan tabuhyang unggul dalam popularitas secara jelas telah memberi pengaruh terhadap ansambel gamelan Bali di luar gong kebyardan kesenian Bali secara lebih luas.

Dalam suatu kasus yang lebih ekstrim beberapa ansambel musik Bali semisal gamelan angklung, gamelan joged bumbung, gamelan semar pegulingan, gamelan gong gede dan ansambel gamelan Bali lainnya beberapa telah berubah secara bentuktabuh gong dan ciri khasnya. Bentuk tabuh gong dan ciri khas gamelan-gamelan tersebut dewasa ini telah dikesampingkan dan cenderung lebih memilih "kebyar" sebagai acuan dalam penggarapan-penggarapan tabuh gong gamelan Bali.

Pandangan fragmatis peneliti yang bersumber dari fenomena gong kebyar di Bali adalah kemungkinan ciri khas beberapa gamelan-gamelan Bali akan hilang di masa depan tanpa adanya kesadaran akan hal tersebut. Sehingga melalui penelitian ini kajian gong kebyar secara tekstual (intramusikal) sangat diharapkan sebagai media informasi dan edukasi kepada masyarakat untuk sadar bahwa musik Bali tersebut lahir dengan berbagai varian rasa musikal. Tidak hanya karena alasan pengembangan dan popularitas, masyarakat mengesampingkan identitas jenis-jenis ansambel gamelan Bali dengan menjadikan semua seperti "kebyar".

Nafas kebyar atau seni kakebyaran sebagai identitas gong kebyar digunakan sebagai kapital budaya untuk mengidentikkan gamelan Bali. Popularitas gong kebyar berkaitankaraktermusikal dan bentuk tabuh gong "kebyar" banyak dipandang sebagai identitas musik Bali.I Made Bandem dalam bukunya yang berjudul Gamelan Bali Di Atas Panggung Sejarah menyebutkan kini di Bali terdapat 30 jenis ansambel gamelan namun tidak dapat dipungkiri bahwa gong kebyar merupakan yang paling populer, terlebih lagi dengan ciri khas "kebyar atau seni kakebyaran" yang dimilikinya. Kebyar sebagai kapital budaya untuk mempertahankan identitas gamelan Bali menjadi sangat perlu dijelaskan lebih lanjut. Mengapa "kebyar" yang dipilih sebagai kapital budaya sebagai identitas musik Bali bukan gaya-gaya dari ansambel gamelan Bali lainnya? Ungkapan tersebut muncul jelas sangat berkaitan dengan unsur intramusikal yang 
sarat dalam istilah "kebyar". Sehingga perlu ada penjelasan lebih lanjut tentang bentuk musikal serta unsur-unsur yang mendukung bentuk tabuh gong dapat disebut "kebyar". Selain untuk mengetahui bagaimana bentuk kebyar, lebih jauh lagi adalah untuk menemukan jawaban mengapa harus kebyar yang dijadikan sebagai kapital budaya untuk mencirikan identitas musik Bali.

Gong kebyar setiap tahun selalu memperoleh apresiasi paling tinggi dari masyarakat Bali dan mancanegara dalam runtutan acara Pesta Kesenian Bali (PKB). Oleh pencetusnya I.B. Mantra, PKB yang lahir pada tahun 1979 dijadikan strategi pembinaaan dan pengembangan kebudayaan Bali (Bandem, 2008: 109). Pertunjukan festival yang saat ini telah berubah menjadi parade gong kebyar selalu ditempatkan di panggung utama, yaitu panggung Ardha Candra Art Center Denpasar. Tidak sembarangan jenis kesenian yang dapat melakukan pertunjukan di panggung utama yang berkapasitas sekitar 5.000 orang pada acara PKB. Terbukti parade gong kebyar dalam acara PKB selalu ditampilkan di sana sebagai wujud penghargaan atas nama pelestarian dan identitas.

Gong kebyar yang sudah mendunia digunakan sebagai media untuk menjadi salah satu pendukung pariwisata Bali untuk "go-internasional". Popularitas gong kebyar digunakan sebagai modal kapital untuk mempertahankan kekuasaan. Kapital merupakan hubungan sosial, artinya suatu energi sosial yang hanya ada dan membuahkan hasil dalam arena perjuangan di mana ia memproduksi dan mereproduksi. Setiap kepemilikan yang terkait dengan kelas menerima nilainya dan efektivitasnya dari hukum-hukum khas setiap arena: dalam praktik, artinya dalam suatu arena khusus, semua disposisi dan kepemilikan obyektif (kekayaan ekonomi atau budaya) (Bourdieu, 1979: 127). Pemilik kapital mengelabui masyarakat Bali dengan menerapkan politik balas budi melalui penghargaan atas nama pelestarian dan identitas. Politik ini dapat dilihat dari bagaimana gong kebyar dibentuk sebagai musik populer yang terkesan berbeda penyikapannya dengan jenis gamelan Bali lainnya. Gong kebyar selalu mendapatkan penghargaan yang berbeda terlebih pada acara PKB. Selain itu gong kebyar selalu diperkenalkan kepada negara-negara lain di dunia sebagai identitas musik khas Bali. Walaupun kenyataannya Bali memiliki 30 jenis ansambel 
gamelan, namun politik kapital telah memproduksi pengetahuan bahwa identitas musik Bali adalah gong kebyar. Pemilik kapital mempertahankan kekuasaan mereka melalui penghargaan-penghargaan terhadap produk seni dan budaya seperti pada kasus gong kebyar. Memberi dukungan terhadap penyelenggaraan acara apresiasi produk seni dan budaya seperti PKB sehingga masyarakat Bali tidak menyadari bahwa mereka sendiri sedang masuk dalam arena perjuangan kekuasaan kapital.

Masyarakat Bali secara khusus seniman dan penikmat seni sebagian besar kesadarannya dialihkan menggunakan kenyamanan dari pemilik kapital. Kesadaransosial dialihkan menggunakan kenyamanan dan pandangan romantisme yang selalu dibangun para pemilik kapital. Pemilik kapital melakukan ini untuk memberi kesan bahwa Bali selalu baik-baik saja berikut dengan seni dan budayanya. Sehingga masyarakat dengan kesadaran yang dimiliki tidak akan melakukan penelusuran lebih lanjut apalagi melawan atas apa yang sebenarnya mereka hadapi. Masyarakat akan kesulitan untuk menjelaskan apa yang sebenarnya terjadi dan apa yang bisa dilakukan untuk mengatasi ini.

Permasalahan gong kebyar di Bali tersebut sangat penting untuk diketahui oleh masyarakat sehingga perlu adanya penelitian lebih lanjut untuk membahasnya. Mengapa ini menjadi sangat penting untuk diteliti? Seperti yang sudah dijelaskan bahwa masyarakat Bali sudah sekian lama tenggelam dalam pandangan-pandangan romantisme yang dibangun pemilik kapital. Diharapkan dengan adanya penelitian ini masyarakat Bali mampu tercerahkan, minimal mampu untuk menjelaskan apa yang sebenarnya terjadi seni dan budaya mereka. Musik dalam hal ini gong kebyar saat ini bukan hanya milik masyarakat Bali dan masyarakat pencinta seni dan budaya Bali, namun secara tidak langsung telah menjadi produk kapital melalui kapital budaya yang dimiliki dalam arena perjuangan kekuasaan. Bagaimana mekanisme dan strategi dominasi dalam kasus gong kebyar ini di bahas dalam penelitian ini pada bagian selanjutnya. 


\section{Bentuk Tabuh Gong dan Seni Kakebyaran Sebagai Kapital Budaya.}

Bentuk tabuh gong dan seni kakebyaran sebagai kapital budaya akan dijelaskan pada bagian ini. Bentuk tabuh gong yang populer dengan istilah "kebyar atau kakebyaran" akan menjadi penekanan pembahasan, karena kedua bentuk istilah tersebut sering diidentikkan dengan identitas musik Bali. Sebelum menuju pada pemahaman tentang bentuk tabuh gong"kebyar atau kakebyaran" nampaknya terlebih dahulu penjelasan tentang kedua istilah tersebut sangat perlu untuk dibahas.

Kebyaratau kakebyaran merupakan istilah yang muncul dan melekat pada ansambel gamelan Bali golongan baru yaitu gong kebyar. Adanya hubungan yang erat antara Bali dengan dunia Barat pada Masa Penjajahan Belanda (1846-1945) pada tahun 1914 di Bali Utara lahir sebuah gamelan gaya baru yang disebut gamelan gong kebyar (Bandem, 2013: 71). Dengan lahirnya gamelan gaya baru tersebut kemudian menandai lahirnya pula identitas musik baru di Bali yaitu “kebyar". Kebyar sebagai sebuah bentuk seni karawitan Bali yang menggunakan susunan instrumen, pola garap gending, pola penyajian teknik tabuhan instrumen dan karakter baru, sehingga tepat sekali jika gamelan itu dimasukkan ke dalam kelompok gamelan baru (Senen, 2002: 17). Pemberian nama "kebyar" terhadap karya seni karawitan Bali tersebut sangatlah beralasan, karena perangkat gamelan baru itu betul-betul mampu mengekspresikan karakter "kebyar", yaitu keras, lincah, cepat, agresif, mengejutkan, muda, enerjik, gelisah, semangat, optimis, kejasmanian, ambisius, dan penuh emosi (Aryasa, 1977: 8). Semangat kebaruan yang ditawarkan oleh gong kebyar dengan ciri khas "kebyar" yang dimiliki menjadi tawaran baru dalam perbendaharaan karawitan Bali.

Kebyar selain sebagai karakter musikal gong kebyar juga merupakan istilah yang digunakan untuk menyebutkan pola tabuhangamelan mirip unisono dalam istilah music baratdalam permainan gong kebyar. Menurut I Wayan Dibia sebelum lahirnya gamelan gong kebyar terlebih dahulu adalah lahirnya tabuhtabuh atau lagu-lagu rasa kebyar. Dengan kata lain, kelahiran kebyar di Bali berawal dari munculnya gagasan atau konsep musikal yaitu musik keras dan 
dinamis yang disebut kebyar (Dibia, 2012: 116). Pola-pola tabuhan mirip unisono yang dimainkan dalam konsep kebyaradalah teknik memainkan gamelan dengan cara dipukul bersama-sama dengan penekanan-penekanan pada pola-pola singkup dalam tempo cepat dan dinamika keras. Pola tabuhan kebyar tersebutlah yang kemudian menjadi salahsatuciri khas dari gamelan gong kebyar.

Setalah lahirnya tari truna jaya yang kini masih tetap bertahan semula bernama kebyar legong yang berarti tari legong yang di-kebyar-kan (Dibia, 2012: 116). Kemudian istilah kebyar tersebut berkembang menjadi genre atau gaya karawitan baru yang tidak terbatas dalam gamelan secara instrumental namun berkembang pada gamelan sebagai iringan seni pertunjukan diluar gamelan. Perkembangan bentuk gaya baru dari karawitan dan seni pertunjukan Bali ini kemudiandiistilahkandengan seni kakebyaran, walaupun padasaat itu masih terbatas di Bali utara.

I Nyoman Mario yang mampu menampilkan sebuah karya yang kini kita kenal sebagai tari kebyar duduk dan kebyar trompong, telah melakukan langkah berani dan pasti bagi pembaharuan tari di Bali. Tari yang benar-benar baru bersamaan dengan mulai menyebarnya gamelan gong kebyar dari Bali utara yang sangat lincah ke Bali selatan, ditampilkan Mario pada tahun 1925 (Soedarsono, 2002: 242). Peristiwa tersebut dapat ditandai dan dikukuhkan bahwa istilah "kebyar atau seni kakebyaran" mulai dikenal di seluruh Bali hingga populer seperti sekarang ini.

Salah satu ciri dari penyajian gamelan gong kebyar adalah adanya tabuhan pasangan gender, penyacah, jublag, jegogan, reong, dan kendang dengan pola tabuhan ubit-ubitan atau kotekan (interlocking) dan oncang-oncangan (imbal) (Senen, 2002: 106-107). Gaya "kebyar atau seni kakebyaran" seperti yang telah disebutkan merupakan ciri khas yang sering digunakan dalam mengidentikkan bentuk musikal gamelan Bali. Meskipun kenyataannya gamelan Bali memiliki banyak teknik-teknik tabuhan dari berbagai instrumen dan ansambel, namun teknik tabuhan ubit-ubitan atau kotekan (interlocking), oncang-oncangan (single stroke), dankebyar (unisono) yang merupakan ciri khas gong kebyar yang paling populer. Teknik-teknik tersebutlah yang sering digunakan sebagai simbol untuk 
mengidentikkan ciri khas musik Bali secara teknik. "Kebyar" kaitannya dengan teknik tabuhandigunakan sebagai kapital budaya untuk memperkenalkan musik Bali ke seluruh dunia, disisi lain ciri khas gamelan Bali lainnya seakan di anak tirikan untuk diperkenalkan. Lebih ekstrim lagi karena adanya "kebyar" beberapa gamelan di Bali telah mengalami pergeseran secara bentuktabuh gong, yaitu menjadikan teknik-teknik kebyar sebagai acuan dalam memproduksi dan mereproduksi bentuk musikal dari ansambel gamelan Bali. Sebut saja gamelangong gede yang merupakan gamelan Bali golongan madya yang identik dengan upacara-upacara ritual dsebagai sajian seni yang berdiri sendiri, sejak adanya "kebyar" perubahan "tabuh gong" gong gede ini ditandai oleh munculnya gong gede "ngebyar" (gong gede yang menampilkan rasa musikal "kebyar") (Dibia, 2012: 111).Contoh tersebut menggambarkan gong kebyar dengan kapital budayayaitu "kebyar atau senikakebyaran" telah mampu memperlihatkan dominasinya terhadap ansambel atau instrumen gamelan Bali lainnya.

Kebyar sebagai kapital budaya yang dimiliki oleh gamelan gong kebyar dengan segala semangat kebaharuan dan segala romantisme yang ditawarkan digunakan oleh pemilik kapital untuk memperkenalkan seni musik Bali melalui gamelan. Kapitalbudaya "kebyar" digunakan sebagai kekuatan bagi pemilik kapital untuk mempertahankan kekuasaan dalam arena perjuangan kekuasaan. Popularitas "kebyar" yang dimiliki gong kebyar dibangun sedemikian rupa oleh pemilik kapital dengan mengesampingkan ciri-ciri gamelan Bali di luar gong kebyar yang jelas bukan hanya "kebyar".Kebyar sebagai identitas gong kebyar digunakan sebagai kapital budayauntuk mempertahankan kekuasaan dalam arena perjuangan kekuasaan dalam dunia pariwisata di Bali.

Teknik tabuhan atau polatabuhan kebyar merupakan kapital budaya yang digunakan sebagai media mempertahankan dan memperoleh kekuasaan. Kebyar memiliki tiga ciri khas tekniktabuhan seperti yang disebutkan pembahasan sebelumnya. Ke-tiga teknik tersebut yaitu ubit-ubitan atau otekan (interlocking), oncang-oncangan (single stroke), dan kebyar (unisono).Berikut ini akan dilampir contoh bentuk teknik-teknik "kebyar" tersebut dalam bentuk notasi: 
a. Ubit-ubitan atau kotekan (interlocking).

Pola polos:

_.6 j1. j61 j.6 j1. j61 j.6j1. j6. j16 j.1 j6. $j 16 j .1 j 6 \cdot j 16$

Pola sangsih:

-3. j23 j.2 j3. j23 j.2 j3. j23 j.2 j.3 j2. j32 $j \cdot 3 j 2 \cdot j 32 j \cdot 3$

b. Oncang-oncangan (single stroke).

Pola polos:

$\begin{array}{rlllllllllllllll}1 & 3 & 6 & 1 & 3 & 6 & 1 & 3 & 6 & 1 & 3 & 6 & 1 & 3 & 6 & 1\end{array}$

Pola sangsih:

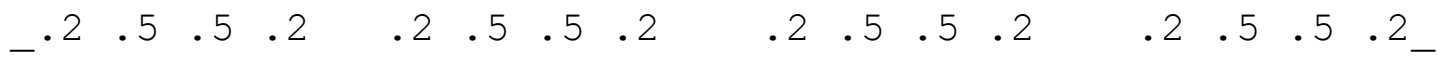

c. Kebyar (unisono).

Potongan pola kebyar tari kebyar duduk:

g6 j12 g6j21 j2. j56 j56 g5

\section{Gong Kebyar Sebagai Kapital Budaya Dalam Arena Perjuangan Kekuasaan}

Modal kapital seperti yang dikemukakan Bourdieu, defenisi modal ini sangat luas dan mencakup hal-hal material (yang dapat memiliki nilai simbolik) dan berbagai atribut 'yang tak tersentuh', namun memiliki signifikansi secara kultural, misalnya prestise, status, dan otoritas (yang dirujuk sebagai modal simbolik), serta modal budaya (yang didefinisikan sebagai selera bernilai budaya dan pola-pola konsumsi) (Bourdieu, 1986a: 58). Kapital budaya dapat mencakup rentangan luas properti, seperti seni, pendidikan, bentuk-bentuk bahasa (Harker, 2009: 16). Mengacu dari pemahamankapitalbudayatersebut kita dapat memahami “kebyar" sebagai produk budaya dalam wujud seni musik, dapat dijadikan sebagai 
kapital budaya. Gong kebyar mampu mempertahankan kekuasaannya di blantika musik Baliyaitukarawitan Bali tiada lain adalah karena adanya kapital budaya yang melekat padanya.

Gong kebyar sebagai kapital budaya digunakan sebagai identitas sosial masyarakat Bali. Masyarakat Bali seakan-akan turut meng-amin-ni apa yang dibentuk secara kolektif oleh kelompok sosial sebagai identitas mereka. Identitas sosial mengacu pada kualitas yang unik dari seseorang, nilai-nilai, dan atributatribut serta merefleksikan latar belakang sejarah personal di mana identitas sosialnya mengacu pada kategori sosial yang dimiliki orang tersebut, pernah dimiliki atau saling membagi nilai-nilai yang penting (Crozier, 2003: 71). Melalui nilai dan atribut "kebyar" yang terkandung dalam gong kebyar, personal mengacu kategori sosial secara luas sebagai identitas sosial.Dengan demikian bentuk tabuh gong "kebyar" sebagai kapital budaya telah mempengaruhi personal dan masyarakat dalam ruang sosial, melalui refleksi latar belakang sejarah tentang kepemilikan identitas sehingga akhirnya menerima pandangn umum (common sense) sebagai identitas personal maupun sosial mereka.

Ambiguitas yang diakibatkan kesalahpahaman atas kode-kode itu sendiri menghasilkan 'ilusi pemahaman langsung' yang, pada gilirannya, 'menuntun pada pemahaman ilusif yang didasarkan pada kode yang dimengerti secara keliru' (Bourdieu, 1968: 590). Kesalah pahaman terhadap kode-kode yang melekat pada seni merupakan hasutan dari ideologi "pandangan segar" dalam apresiasi seni. "Kebyar" sebagai kode yang erat dengan "pandangan segar" secara efektif telah melegitimasi beberapa kode, sementara mencemarkan kode lainnya pada gamelan Bali. Seniman atau khalayak seni seharusnya sadar bahwa seni dalam hal ini gong kebyar merupakan hasil dari konstruksi sosial dengan berbagai kode-kode yang disematkan padanya, sehingga untuk memahaminya tidak cukup dangan "pandangan segar". Gong kebyar sebagai sebuah karya seni dapat dilihat melalui unsur intrinsik atau intramusikalnya, yaitu "kebyar" sebagai salah satu genre atau gayakarawitan Bali yang terbukti telah melegitimasi gayakarawitan Bali lainnya.

"Menjadi logika khas arena perjuangan, apa yang dipertaruhkan dan jenis modal yang diperlakukan untuk berperandi dalam permainan, yang mengarahkan 
logika kepemilikan yang menentukan hubungan antara kelas sosial dan praktiknya" (Bourdieu, 1979: 126).Kelas sosial menurut pandangan Bourdieu ditujukan kepada personal dan masyarakat dalam ruang sosial. Pandangan kelas sosial pada kasus gong kebyar ini memperlihatkan ranah yang sedikit berbedadari artikelas sosial yang tidak ditunjukkan Bourdieu. Pandang Bourdieu tentang kelas sosial lebih ditekankan pada aktivitas dan ruang lingkup subjek atau pelaku dan penikmat seni dalam menyikapi karya seni sebagai objek, namun kelas sosialyang dimaksuddisini tidak dapat ditampik bahwa melekat pada objek yaitu seni itu sendiri. Kelas sosial yang jelas dan sangat verbal dalam penggambaran Bourdieu merupakan perlakuan subjek terhadap objek, namun dalam kasus ini penulis melihat kekosongan teoritis tentang apa yang diungkapkan Bourdieu. Subjek sebagai pelaku dalam ruang sosial memang memiliki kontribusi yang jelas dalam pembentukan identitas kelas sosial, namun objek sebagai objek materi tidak bisa begitu saja dilupakan dalam kontribusinya membentuk kelas sosial. "Kebyar" sebagai unsur intramusikal dari gong kebyar sebagai objek telah memberi pemahaman bahwa objek mampu membangun identitas dan kelasnya sendiri dalam ranah musik dalam hal ini gamelan Bali. Melalui tawaran intramusikal “kebyar", gong kebyar sebagai objek memperoleh kelas sosialnya dalam ranah karawitan Bali atau kasta tertinggi dalam gamelan Bali,namun mengacu dari Bourdieu tidak dapat dipungkiri melalui personal dan masyarakat subjek memperoleh kelas sosial mereka melalui musik.

Kapital budaya yang dimiliki oleh gong kebyar dengan identitas "kebyar" mampu berkontribusi banyak dalam arena perjuangan kelas sosial dalam ranah musik atau gamelan Bali. Kebyar sebagai kapital budaya mampu menjadikan dirinya dominan dalam arena perjuangan kelas sosial melalui tawaran intramusikal yang dimiliki. Gong kebyar dapat memproduksi dan mereproduksi dominasi mereka pada kelas sosial tertinggi dalam gamelan Bali melalui kapital budaya yang dimiliki.

\section{Kesimpulan}


Gong kebyar seperti yang kita ketahui merupakan ansambel gamelan Bali yang paling populer. Popularitasnya tidak hanya mencakup ruang lingkup masyarakatBali sebagai pemilik Budaya, namun lebih luas lagi masyarakat duniasebagaikonsumen. Kebyar merupakan sebuah pencapaian spektakuler dalam gamelan Bali seperti yang diungkapkan dalam artikelI Made Bandem dalam buku seni kakebyaran. Gong kebyar dengan identitas "kebyar" mampu mencapai kasta tertinggi popularitas gamelan Bali.

Kebyar sebagai tawaran intramusikal khas gong kebyar mampu melegitimasi tawaran taste musikal dari ansambel Bali lainnya. Munculnya "kebyar" menimbulkan pergeseran secara bentuk tabuh gong dari berbagai gamelan di Bali. Pengaruh gamelan gong kebyar terhadap gamelan Bali lainnya adalah repertoar, ungkapan musikal, motif lagu, dan tata penyajian (Sugiartha, 2008: 53). Teknik permainan yang menjadi identitas gamelan gong kebyar antara lain ubit-ubitan atau kotekan (interlocking), oncang-oncangan (single stroke), kebyar (unisono) dijadikan acuan dalam memproduksi dan mereproduksi karya dari gamelan Bali lainnya. Identitas "kebyar" sebagaimilik gong kebyarmemperlihatkan legitimasinya terhadap gamelan Bali lainnya.

“Kebyar" sebagai identitas gong kebyar memiliki kapital budaya yang melekat padanya.Kapital budaya yang melekat pada "kebyar" secara intramusikal mampu mendominasi dalam arena perjuangan kelas sosial.Melalui tawaran intramusikal "kebyar", gong kebyar sebagai objek memperoleh kelas sosialnya dalam ranah musik "kasta tertinggi dalam gamelan Bali" namun mengacu dari Bourdieu tidak dapat dipungkiri melalui personal dan masyarakat subjek memperoleh kelas sosial mereka melalui musik.

\section{Daftar Pustaka}

Aryasa, I W.M. 1976/1977. Perkembangan Karawitan Bali, Denpasar: Proyek Sasana Budaya Bali. 2008. Lomba-lomba Gong Kebyar Yang Telah Lewat dan Yang Akan Datang, Denpasar: Bali Mangsi Foundation. 
Bandem, I Made. 2008.Kebyar Sebuah Pencapaian Spektakuler Dalam Kesenian Bali. Denpasar: Bali Mangsi Foundation.

Bandem, I Made. 2013. Gamelan Bali Di Atas Panggung Sejarah. Denpasar: BP STIKOM Bali.

Bourdieu, P., J. C. Chamboredon dan J. C. Passeron.(ed. Pr. 1968).Le Matier de Sociologue. Paris: Mouton.

1979. Algeria 1960: The Disenchantment of the World, the Sense of Honour, the Kebyle House or the World Reversed. Cambridge: Cambridge University Press.

1986. 'The Form of Capital', dalam J. G. Richardson (ed), Handbook of Theory and Research for the Sociology of Education.New York: Greenwood Press.

Crozier, M. dan Friedberg, E. 1977. L'acteur et le Systeme. Paris: Seuil.

Dibia, I Wayan. 2008. Seni Kakebyaran. Denpasar: Bali Mangsi Foundation. . 2012. Geliat Seni Pertunjukan Bali. Denpasar: Buku Arti.

Harker, Richard. Mahar, Cheelen. Wilkes, Chris. 1990. An Introduction to the Work of Pierre Bourdieu: The Practice Theory. London: The Macmillan Press.

Sugiartha, I Gede Arya. 2008. Pengaruh Gong Kebyar Terhadap Gamelan lainnya di Bali. Denpasar: Bali Mangsi Foundation. 